\title{
Acclimation of Growth and Photosynthesis in Petunia Seedlings Exposed to High-intensity Blue Radiation
}

\author{
Joshua K. Craver and Krishna S. Nemali \\ Department of Horticulture and Landscape Architecture, Purdue University, West Lafayette, IN \\ 47907
}

\author{
Roberto G. Lopez \\ Department of Horticulture, Michigan State University, 1066 Bogue Street, East Lansing, MI 48824
}

\begin{abstract}
AdDitional INDEX words. A-PPFD responses, $\mathrm{CO}_{2}$, controlled-environment agriculture, light-emitting diode, plug, solesource lighting

Abstract. Indoor production of bedding plant seedlings using sole-source radiation may present value in increasing uniformity and consistency compared with greenhouse production. However, information on physiological acclimation related to growth and photosynthesis in seedlings exposed to high-intensity blue radiation and elevated $\mathrm{CO}_{2}$ is limited. Seedlings of petunia $($ Petunia $\times$ hybrida $)$ 'Dreams Midnight' were exposed to red $($ peak $=660 \mathrm{~nm}): \mathrm{blue}($ peak $=$ $451 \mathrm{~nm})$ radiation ratios of 50:50 $\left(R_{50}: B_{50}\right)$ or $90: 10\left(R_{90}: B_{10}\right)$ and radiation intensities of 150 or $300 \mu \mathrm{mol} \cdot \mathrm{m}^{-2} \cdot \mathrm{s}^{-1}$ under two $\mathrm{CO}_{2}$ regimes of 450 or $900 \mu \mathrm{mol} \cdot \mathrm{mol}^{-1}$. Shoot dry mass (SDM), leaf area index (LAI), internode length, and whole-plant photosynthesis and light-use efficiency (LUE) responses to increasing radiation intensity were measured. In addition, leaf photosynthetic rate (A) was measured at ambient and supra-optimal $\mathrm{CO}_{2}$ concentrations for plants grown under $450 \mu \mathrm{mol} \cdot \mathrm{mol}^{-1} \mathrm{CO}_{2}$. Our results indicated growth (based on SDM, LAI, and internode length) was lowered for seedlings produced under $R_{50}: B_{50}$ compared with $R_{90}: B_{10}$. However, we observed an increase in wholeplant light-saturated photosynthesis $\left(A_{g, m a x}\right)$ and whole-plant light saturation point (LSP) under $R_{50}: B_{50}$ compared with $R_{90}: B_{10}$. In addition, we observed lower $L U E$ below and higher $L U E$ above a radiation intensity of 500 $\mu \mathrm{mol} \cdot \mathrm{m}^{-2} \cdot \mathrm{s}^{-1}$ in seedlings grown under $R_{50}: B_{50}$ compared with $R_{90}: B_{10}$. Based on our results, seedling growth was lowered under a high proportion of blue radiation mainly due to lower radiation interception (due to lower LAI and shorter internode length) and LUE of intercepted radiation at the intensities used. Higher $A_{g, m a x}$ and LSP in $R_{50}: B_{50}$ compared with $R_{90}: B_{10}$ under higher radiation intensities was likely in part due to higher $L U E$. Further investigation revealed $A$ was higher at both optimal and supra-optimal $C_{2} O_{2}$ concentrations under $R_{50}: B_{50} \operatorname{compared~with~} R_{90}: B_{10}$, indicating a lack of stomatal effects of a higher proportion of blue radiation on carboxylation and LUE. We hypothesize that higher LUE in $R_{50}: B_{50}$ compared with $R_{90}: B_{10}$ under higher radiation intensities is due to improved photochemical quenching from increased biosynthesis of carotenoids and anthocyanins. The results from our study generated fundamental information on growth and photosynthetic responses to excess blue radiation, data that can be further used in optimizing plant production in controlled environments.
\end{abstract}

With the development of light-emitting diodes (LEDs) and advancements in environmental control technologies, indoor production using sole-source lighting (SSL) is a potential alternative to traditional greenhouse production for many high-value specialty crops. Specifically, seedlings have been proposed for indoor production due to their high value, relatively short production cycle, and high production density in small tray sizes (Park and Runkle, 2017; Randall and Lopez, 2015). In a recent study conducted by Banerjee and Adenaeuer

Received for publication 29 July 2019. Accepted for publication 19 Dec. 2019. Published online 21 February 2020.

We gratefully acknowledge Jillian Malecki and Zachary Oravec for greenhouse and laboratory assistance; Philips Lighting for light-emitting diode fixtures and funding; Ball Horticultural Co. for seed; Sun Gro Horticulture for growing media, and Everris NA Inc. for fertilizer.

The use of trade names in this publication does not imply endorsement by Purdue University, Michigan State University, or Colorado State University of products named nor criticism of similar ones not mentioned.

Current address for J.K.C.: Department of Horticulture and Landscape Architecture, Colorado State University, Fort Collins, CO 80523.

J.K.C. is the corresponding author. E-mail: Joshua.Craver@colostate.edu.

This is an open access article distributed under the CC BY-NC-ND license (https://creativecommons.org/licenses/by-nc-nd/4.0/).
(2014), the authors discuss that while vertical, indoor production applications are possible, extensive research regarding production techniques is still required to optimize these systems. With an increased understanding of seedling physiological responses to radiation intensity, radiation quality, and $\mathrm{CO}_{2}$ concentration, informed adjustments to these inputs can be made to optimize production for indoor controlled environments.

Specific to seedlings, increased radiation intensities generally lead to increased quality and dry mass accumulation (Faust et al., 2005; Oh et al., 2010; Pramuk and Runkle, 2005). For example, Graper and Healy (1992) grew petunia (Petunia $\times$ hybrida) 'Red Flash' seedlings under multiple greenhouse lighting scenarios and found higher daily light integral (DLI) increased growth rate and carbohydrate partitioning. Chlorophylls $a$ and $b$ absorb radiation maximally in the red (663 and $642 \mathrm{~nm}$, respectively) and blue (430 and $453 \mathrm{~nm}$, respectively) wavebands, with a strong correlation between absorption peaks and maximum photosynthetic efficiency (Kopsell et al., 2014). Therefore, many LED SSL applications have focused on red and blue wavelengths to maximize chlorophyll absorption and increase plant productivity (Massa et al., 2008; Mitchell et al., 2012). 
Based on findings in other crops, blue wavelengths result in photomorphogenic responses including growth inhibition and reduced stem extension (Cosgrove, 1981; Kigel and Cosgrove, 1991; Runkle and Heins, 2001). Hernández and Kubota (2016) found increased percentages of blue radiation (peak $=455 \mathrm{~nm}$; up to $75 \%$ at a radiation intensity of $100 \mu \mathrm{mol} \cdot \mathrm{m}^{-2} \cdot \mathrm{s}^{-1}$ ) provided to cucumber (Cucumis sativus) 'Cumlaude' seedlings decreased leaf area (LA) and increased leaf mass area (LMA). Blue radiation alone or in combination with red wavelengths also affects stomatal density and aperture, with phototropins (phot1 and phot2) believed to be the photoreceptors responsible for mediating this response (Kinoshita et al., 2001; Zeiger et al., 2002). Further, increased stomatal density and aperture under high percentages of blue radiation may increase a plant's capacity for $\mathrm{CO}_{2}$ uptake, ultimately increasing photosynthesis (Kinoshita et al., 2001). These findings indicate plant responses to blue radiation are different at whole-plant and leaf scales. Blue radiation appears to promote photosynthesis at the leaf scale, while also inhibiting growth at the whole-plant scale. It is important to understand the physiological relationship between the promotion of leaf photosynthesis and inhibition of overall plant growth under high intensities of blue radiation in order to optimize production in controlled environments.

In addition to radiation, $\mathrm{CO}_{2}$ is a limiting input of photosynthesis (Tremblay and Gosselin, 1998). An atmosphere enriched with $\mathrm{CO}_{2}$ is associated with increased carbon fixation rate, water-use efficiency, and nitrogen-use efficiency (Arp, 1991). As energy consumption costs can be high under indoor or vertical production (Shimizu et al., 2011), $\mathrm{CO}_{2}$ enrichment may aid in increasing crop productivity and overall profits. However, there is evidence showing prolonged exposure to elevated $\mathrm{CO}_{2}$ concentrations may provide declining benefits to photosynthesis over time, and suppression of plant growth may follow (Arp, 1991; Makino and Mae, 1999). Specifically, the positive effects of elevated $\mathrm{CO}_{2}$ concentrations may be limited during long-term exposure when sink availability becomes saturated (Arp, 1991). While elevated $\mathrm{CO}_{2}$ concentrations have generally been viewed as beneficial for plant growth, limited information is available regarding how to best use $\mathrm{CO}_{2}$ in controlled environments (Prior et al., 2011) alongside the interactive effects of radiation intensity and quality.

Our objective was to study the interactive effect of radiation intensity and quality on growth and photosynthetic responses of petunia seedlings produced under SSL maintained at either an ambient or enriched $\mathrm{CO}_{2}$ concentration. We postulated: 1) photosynthesis would be higher in seedlings grown under high radiation intensities and elevated $\mathrm{CO}_{2}$ concentrations, ultimately leading to increased growth; and 2) the efficiency with which plants use incident radiation would decrease with higher percentages of blue radiation, leading to a reduction in photosynthesis and overall growth.

\section{Materials and Methods}

Plant material and growth Chamber EnVironment. Seeds of petunia 'Dreams Midnight' were sown in 128-cell trays filled with a medium comprised of (by volume) 65\% peat, $20 \%$ perlite, and 15\% vermiculite (Fafard Super Fine Germinating Mix; Sun Gro Horticulture, Agawam, MA). Trays were divided into 40-cell sections to facilitate data collection. Trays were immediately placed under treatment conditions with a 16-h photoperiod (0600 to $2200 \mathrm{HR}$ ) in walk-in growth chambers (C5 Control System; Environmental Growth Chambers, Chagrin Falls, $\mathrm{OH})$. The air temperature and relative humidity set points for both chambers were $22 / 18{ }^{\circ} \mathrm{C}$ and $55 \% / 60 \%$ (day/night), respectively, and were measured and logged every $15 \mathrm{~min}$ by a data logger (DL1, Environmental Growth Chambers). Seedlings were misted manually to maintain media moisture until germination occurred. Upon hypocotyl emergence, seedlings were irrigated with $16 \mathrm{~N}-0.94 \mathrm{P}-12.3 \mathrm{~K}$ water-soluble fertilizer (Jack's LX Plug Formula for High Alkalinity Water; J.R. Peters, Allentown, PA) providing $\left(\mathrm{mg} \cdot \mathrm{L}^{-1}\right)$ : $100 \mathrm{~N}, 10 \mathrm{P}, 78$ $\mathrm{K}, 18 \mathrm{Ca}, 9.4 \mathrm{Mg}, 0.10 \mathrm{~B}, 0.05 \mathrm{Cu}, 0.50 \mathrm{Fe}, 0.25 \mathrm{Mn}, 0.05 \mathrm{Mo}$, and $0.25 \mathrm{Zn}$.

Treatment conditions. A multilayer (i.e., vertical) production system was used in the growth chambers for the establishment of radiation treatments. Radiation quality treatments consisted of ten red and six blue LED arrays providing red $($ peak $=660 \mathrm{~nm}):$ blue $($ peak $=451 \mathrm{~nm})$ radiation ratios of 50:50 $\left(\mathrm{R}_{50}: \mathrm{B}_{50}\right)$ or 90:10 $\left(\mathrm{R}_{90}: \mathrm{B}_{10}\right)$ (Philips GreenPower LED research modules; Koninklijke Philips Electronics, Amsterdam, The Netherlands) mounted to stainless steel shelves $(123 \mathrm{~cm}$ long and $61 \mathrm{~cm}$ wide) $40 \mathrm{~cm}$ above the crop canopy. Radiation intensity treatments consisted of two levels, 150 and 300 $\mu \mathrm{mol} \cdot \mathrm{m}^{-2} \cdot \mathrm{s}^{-1}$ [average photosynthetic photon flux density $(P P F D)$; 400-700 nm], achieved using dimming units. Thus, a 16 -h photoperiod provided plants with a DLI of 8.6 or 17.3 $\mathrm{mol} \cdot \mathrm{m}^{-2} \cdot \mathrm{d}^{-1}$ for the radiation intensities of 150 and 300 $\mu \mathrm{mol} \cdot \mathrm{m}^{-2} \cdot \mathrm{s}^{-1}$, respectively. Radiation quality and intensity were measured at the beginning of each experimental replication by taking nine individual spectral scans per treatment using a spectroradiometer (BLACK-Comet ultraviolet-VIS; StellarNet, Tampa, FL). Each growth chamber maintained a separate $\mathrm{CO}_{2}$ concentration set point of 450 or $900 \mu \mathrm{mol} \cdot \mathrm{mol}^{-1}$ measured and logged every $15 \mathrm{~min}$ by a data logger (DL1), with an average $\mathrm{CO}_{2}$ concentration $( \pm \mathrm{SD})$ of $446 \pm 19$ and $926 \pm 55 \mu \mathrm{mol} \cdot \mathrm{mol}^{-1}$, respectively, across three experimental replications.

Each treatment environment contained four 40-cell trays. Fixed-mounted infrared thermocouples (OS36-01-T-80F; Apogee Instruments, Logan, UT) were installed on each shelf to measure leaf temperature, and precision thermistors (ST-100, Apogee Instruments) measured air temperature within each treatment. Air and leaf temperature were measured every $15 \mathrm{~s}$, and the average was logged every $15 \mathrm{~min}$ by a data logger (model CR1000; Campbell Scientific, Logan, UT) (Table 1).

Growth Data Collection. At 14, 21, and $28 \mathrm{~d}$ after hypocotyl emergence, one tray was randomly selected from each treatment. Ten seedlings were randomly sampled from each tray for data collection. A LA meter (LI-3100; LI-COR, Lincoln, NE) was used to collect individual seedling LA by removing the leaves at the axil. Leaf area index (LAI) was calculated as the ratio of LA to individual cell surface area of a 128 tray $\left(11.6 \mathrm{~cm}^{2}\right)$. Seedling height was measured, number of nodes were counted, and internode length was calculated as the ratio of seedling height to number of nodes. At harvest, seedling roots, leaves, and stems were washed and dried in a forced air oven maintained at $80{ }^{\circ} \mathrm{C}$ to determine root (RDM), leaf (LDM), and stem dry mass, respectively. Shoot dry mass (SDM) was calculated as stem + LDM. Seedling compactness (milligrams per millimeter) was calculated as the ratio of SDM 
Table 1. Average air and leaf temperature (day/night) \pm SD logged every 15 min by a data logger (model CR1000; Campbell Scientific, Logan, UT). Data for petunia 'Dreams Midnight' seedlings were collected in two separate walk-in growth chamber environments with $\mathrm{CO}_{2}$ concentration set points of 450 and $900 \mu \mathrm{mol} \cdot \mathrm{mol}^{-1}$ and sole-source light-emitting diode treatments with red:blue radiation quality ratios (\%) of 90:10 and 50:50 at target radiation intensities of 150 and $300 \mu \mathrm{mol} \cdot \mathrm{m}^{-2} \cdot \mathrm{s}^{-1}$. Mean values reported are the average across three experimental replications.

\begin{tabular}{|c|c|c|c|c|c|c|}
\hline $\begin{array}{l}\mathrm{CO}_{2} \\
\left(\mu \mathrm{mol} \cdot \mathrm{mol}^{-1}\right)\end{array}$ & $\begin{array}{c}\text { Intensity } \\
\left(\mu \mathrm{mol} \cdot \mathrm{m}^{-2} \cdot \mathrm{s}^{-1}\right)\end{array}$ & $\begin{array}{c}\text { Quality } \\
\text { (red:blue) }\end{array}$ & Day air $\left({ }^{\circ} \mathrm{C}\right)$ & Night air $\left({ }^{\circ} \mathrm{C}\right)$ & Day leaf $\left({ }^{\circ} \mathrm{C}\right)$ & Night leaf $\left({ }^{\circ} \mathrm{C}\right)$ \\
\hline \multirow[t]{3}{*}{$\overline{450}$} & 150 & $50: 50$ & $22.8 \pm 0.8$ & $18.5 \pm 0.2$ & $21.0 \pm 1.1$ & $18.0 \pm 1.1$ \\
\hline & & $90: 10$ & $22.8 \pm 0.6$ & $18.4 \pm 0.2$ & $21.4 \pm 1.1$ & $18.0 \pm 1.2$ \\
\hline & & $90: 10$ & $22.9 \pm 0.7$ & $18.7 \pm 0.2$ & $21.8 \pm 1.0$ & $18.5 \pm 1.2$ \\
\hline \multirow[t]{3}{*}{900} & 150 & $50: 50$ & $22.6 \pm 0.7$ & $18.4 \pm 0.6$ & $21.6 \pm 1.2$ & $18.3 \pm 1.3$ \\
\hline & & $90: 10$ & $22.6 \pm 0.9$ & $18.5 \pm 0.6$ & $21.5 \pm 1.2$ & $18.0 \pm 1.3$ \\
\hline & & $90: 10$ & $22.7 \pm 0.8$ & $18.4 \pm 0.6$ & $21.8 \pm 1.2$ & $18.1 \pm 1.4$ \\
\hline
\end{tabular}

to seedling height at harvest. Leaf mass area [LMA (milligrams per square centimeter)] was calculated as the ratio of LDM to LA at harvest.

Рнотosynthesis data Collection. Gas exchange measurements were collected using a portable photosynthesis meter (LI-6400XT, LI-COR). Photosynthetic responses to increasing radiation (A-PPFD) were conducted using a whole-plant chamber attachment (6400-17 Whole Plant Arabidopsis Chamber, LICOR). Measurements were taken on four seedlings from each treatment, $22 \mathrm{~d}$ after germination, to determine maximum gross photosynthetic rate $\left(\mathrm{A}_{\mathrm{g}, \max }\right)$, maximum net photosynthetic rate $\left(A_{n, \max }\right)$, photosynthetic rate at operating radiation intensity $\left(A_{o p}\right)$, light compensation point (LCP), light saturation point (LSP), and quantum yield $(\alpha)$. Measurements were conducted using an LED light source providing a descending PPFD of $1500,1250,1000,500,250,100,50$, and $0 \mu \mathrm{mol} \cdot \mathrm{m}^{-2} \cdot \mathrm{s}^{-1}$, with 3 min of acclimation at each step. The radiation quality, $\mathrm{CO}_{2}$ concentration, and leaf temperature reflected the environmental set points established for the experiment. Immediately after collecting gas exchange measurements, plants were harvested, and total LA was measured using a LA meter (LI-3100). Gas exchange measurements were adjusted for total LA. Light-use efficiency [LUE (moles per mole)] was calculated as the ratio of leaf gross photosynthesis to incident $P P F D$ using the data from A-PPFD response curves. In addition, leaf photosynthetic responses were conducted for plants grown at the $\mathrm{CO}_{2}$ concentration of $450 \mu \mathrm{mol} \cdot \mathrm{mol}^{-1}$ by taking measurements on four seedlings from each lighting treatment $29 \mathrm{~d}$ after germination using a portable photosynthesis meter (LI-6400XT) with a leaf chamber fluorometer attachment (6400-40 Leaf Chamber Fluorometer, LI-COR). Measurements were collected first at the ambient $\mathrm{CO}_{2}$ concentration, and subsequently increased to a maximum of $1000 \mu \mathrm{mol} \cdot \mathrm{mol}^{-1}$. The radiation quality, radiation intensity, and leaf temperature reflected the environmental set points established for the experiment.

Calculations and statistical analyses. For the A- $P P F D$ analysis, a nonlinear regression was fitted using SigmaPlot (version 12.5; Systat Software, San Jose, CA) and calculations from the fitted equation (Fig. 1) were made using the model described by Nemali and van Iersel (2004):

$$
\mathrm{A}_{\mathrm{n}}=\mathrm{A}_{\mathrm{g}, \max }\left(1-e^{-a \times P P F D / \mathrm{Ag}, \max }\right)-\mathrm{R}_{\mathrm{d}},
$$

where $R_{d}$ (negative value) is dark respiration and light-saturated $A_{n}$ or $A_{n, \text { max }}=A_{g, \text { max }}-R_{d}$. Quantum yield was calculated as the slope of the response curve at a $P P F D$ of zero, and refers to the maximum efficiency at which plants can use incident radiation to fix $\mathrm{CO}_{2}$. The LCP and LSP were calculated by solving the above equation for $A_{n}=0$ and $A_{n}=\left(0.95 \times A_{n, \max }\right)$, respectively.

Due to unforeseen limitations, a $450 \mu \mathrm{mol} \cdot \mathrm{mol}^{-1} \mathrm{CO}_{2}$ concentration was not attainable in one of the walk-in growth chambers used for this experiment. Thus, the two $\mathrm{CO}_{2}$ concentrations were confined to individual growth chamber environments, limiting the ability to randomize this variable in the experimental design. Therefore, $\mathrm{CO}_{2}$ concentrations were evaluated separately for this analysis. For the factors of radiation quality (two levels) and intensity (two levels) within each growth chamber environment, a completely randomized design with a factorial arrangement was used. The experiment was replicated three times, over time, for both morphological and gas exchange measurements in both growth chamber environments. The effects of radiation intensity and quality on measured and estimated responses, including parameters from A-PPFD curves, were compared by analysis of variance using SAS (version 9.3; SAS Institute, Cary, NC) mixed model procedure and Tukey's honestly significant difference test at $P \leq 0.05$.

\section{Results and Discussion}

GrowtH RESPONSES. The interaction between radiation intensity and quality was not significant for SDM at either $\mathrm{CO}_{2}$ concentration (Table 2). However, there was a significant main effect of radiation intensity and quality on SDM, with the greatest values observed under the radiation intensity of 300 compared with $150 \mu \mathrm{mol} \cdot \mathrm{m}^{-2} \cdot \mathrm{s}^{-1}$ and radiation quality of $\mathrm{R}_{90}: \mathrm{B}_{10}$ compared with $\mathrm{R}_{50}: \mathrm{B}_{50}$ (Table 2 ). The observed trends in RDM were generally like those observed for SDM (Table 2). These results indicate overall dry matter accumulation was lower under the radiation intensity of $150 \mu \mathrm{mol} \cdot \mathrm{m}^{-2} \cdot \mathrm{s}^{-1}$ and the radiation quality of $\mathrm{R}_{50}: \mathrm{B}_{50}$. High radiation intensities can increase seedling dry mass accumulation for multiple bedding plant species (Graper and Healy, 1991; Oh et al., 2010; Pramuk and Runkle, 2005). Additionally, Wollaeger and Runkle (2014) evaluated tomato (Solanum lycopersicum) 'Early Girl', salvia (Salvia splendens) 'Vista Red', impatiens (Impatiens walleriana) 'SuperElfin XP Red', and petunia 'Wave Pink' seedlings grown under LED SSL with different red:blue radiation ratios and observed both LA and dry mass decreased as the percentage of blue radiation increased. 


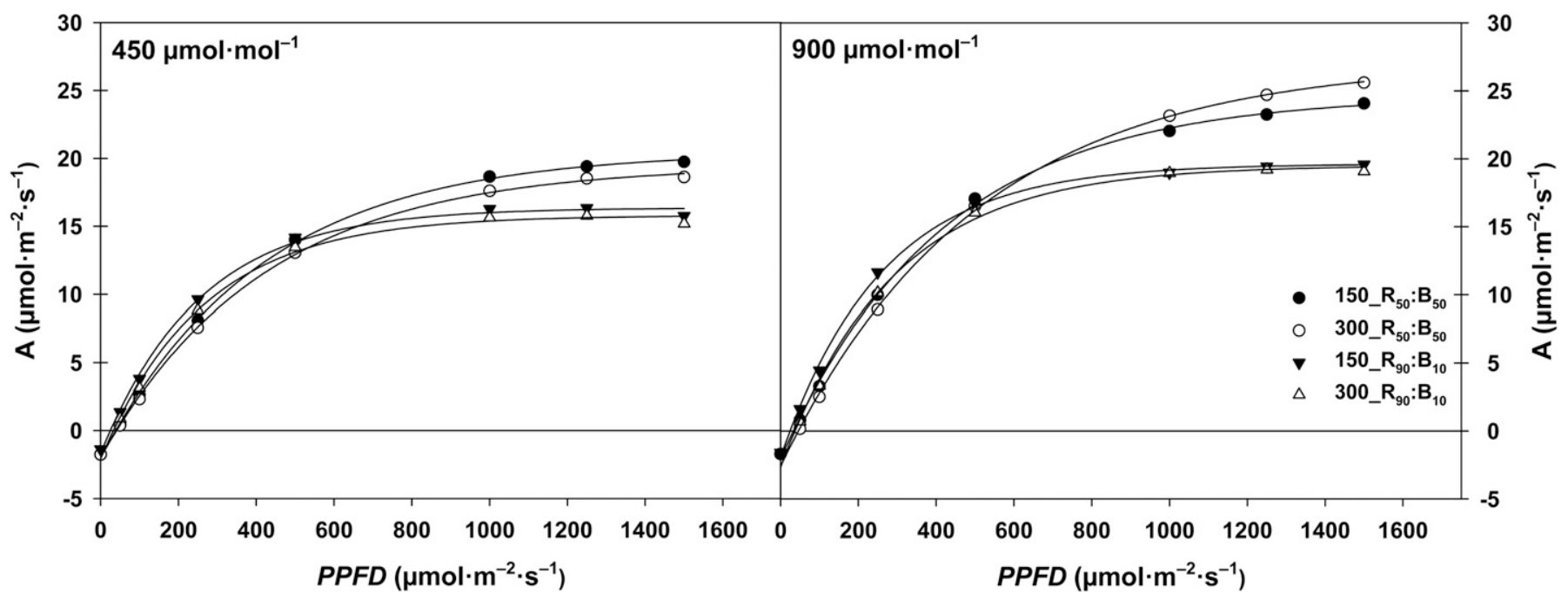

Fig. 1. Relationship between whole-plant photosynthesis (A) and photosynthetic photon flux density ( $P P F D$ ) for petunia 'Dreams Midnight' seedlings grown in walk-in growth chambers with $\mathrm{CO}_{2}$ concentration set points of 450 and $900 \mu \mathrm{mol} \cdot \mathrm{mol}^{-1}$ and sole-source light-emitting diode treatments with red:blue radiation quality ratios $(\%)$ of 90:10 $\left(\mathrm{R}_{90}: \mathrm{B}_{10}\right)$ and 50:50 $\left(\mathrm{R}_{50}: \mathrm{B}_{50}\right)$ at target radiation intensities of 150 and $300 \mu \mathrm{mol} \cdot \mathrm{m}^{-2} \cdot \mathrm{s}^{-1}$. The measurements were taken $22 \mathrm{~d}$ after germination using a portable photosynthesis meter (LI-6400XT; LI-COR, Lincoln, NE). An exponential rise to maximum equation was fitted for all treatment combinations to describe the response. Fitted curves represent the mean responses of four samples across three experimental replications of the study over time $(\mathrm{n}=12)$.

Statistical analysis indicated significant main effects of radiation intensity and quality on seedling compactness, with higher values under the radiation intensity of 300 compared with 150 $\mu \mathrm{mol} \cdot \mathrm{m}^{-2} \cdot \mathrm{s}^{-1}$ and radiation quality of $\mathrm{R}_{90}: \mathrm{B}_{10}$ compared with $\mathrm{R}_{50}: \mathrm{B}_{50}$ (Table 2). Desirable seedling qualities include a limited LA and high dry mass (Oh et al., 2010; Pramuk and Runkle, 2005), which results in a compact appearance. Blue wavelengths are often used to produce a variety of crops due to their role in growth-inhibition responses such as reduced stem extension (Cosgrove, 1981; Kigel and Cosgrove, 1991; Runkle and Heins,
2001). Similarly, blue radiation and high radiation intensities have commonly been associated with an increase in LMA (Hernández and Kubota, 2016; Poorter et al., 2009). In our study, while LMA increased under the radiation intensity of 300 compared with $150 \mu \mathrm{mol} \cdot \mathrm{m}^{-2} \cdot \mathrm{s}^{-1}$, the main effect of radiation quality was not significant (Table 2). Therefore, contrary to the prevailing perception that blue radiation can be used to produce compact bedding plant seedlings, our results indicate petunia seedlings exposed to higher levels of blue radiation were generally smaller in size but not compact.

Table 2. Growth measurements including shoot dry mass [SDM (stem + leaves)], root dry mass (RDM), compactness (milligrams per millimeter), and leaf mass area [LMA (milligrams per square centimeter)] harvested $28 \mathrm{~d}$ after germination for petunia 'Dreams Midnight' seedlings. Seedlings were grown in 128-cell plug trays using walk-in growth chambers with $\mathrm{CO}_{2}$ concentration set points of 450 and $900 \mu \mathrm{mol} \cdot \mathrm{mol}^{-1}$ and sole-source light-emitting diode treatments with red:blue radiation quality (RQ) ratios (\%) of 90:10 and 50:50 at target radiation intensities (RIs) of 150 and $300 \mu \mathrm{mol} \cdot \mathrm{m}^{-2} \cdot \mathrm{s}^{-1}$.

\begin{tabular}{|c|c|c|c|c|c|c|}
\hline $\begin{array}{l}\mathrm{CO}_{2} \\
\left(\mu \mathrm{mol} \cdot \mathrm{mol}^{-1}\right)\end{array}$ & $\begin{array}{c}\text { Intensity } \\
\left(\mu \mathrm{mol} \cdot \mathrm{m}^{-2} \cdot \mathrm{s}^{-1}\right)\end{array}$ & $\begin{array}{c}\text { Quality } \\
\text { [red:blue }(\%)]\end{array}$ & SDM (mg) & RDM (mg) & $\begin{array}{c}\text { Compactness } \\
\left(\mathrm{mg} \cdot \mathrm{mm}^{-1}\right)\end{array}$ & $\mathrm{LMA}\left(\mathrm{mg} \cdot \mathrm{cm}^{-2}\right)$ \\
\hline & & $90: 10$ & 70.1 & 11.6 & 12.1 & $2.6 \mathrm{~b}$ \\
\hline & & $90: 10$ & 127.0 & 20.2 & 19.3 & $4.8 \mathrm{a}$ \\
\hline RI & & & $* * * \mathrm{y}$ & $* * *$ & $* * *$ & $* * *$ \\
\hline RQ & & & $* * *$ & $* * *$ & $* *$ & NS \\
\hline \multirow[t]{4}{*}{900} & 150 & $50: 50$ & 65.5 & $10.0 \mathrm{c}$ & 12.1 & 2.8 \\
\hline & & $90: 10$ & 86.6 & $14.1 \mathrm{~b}$ & 13.8 & 3.2 \\
\hline & 300 & $50: 50$ & 129.0 & $20.7 \mathrm{a}$ & 21.0 & 5.3 \\
\hline & & $90: 10$ & 150.5 & $22.0 \mathrm{a}$ & 21.8 & 5.5 \\
\hline RI & & & $* * *$ & $* * *$ & $* * *$ & $* * *$ \\
\hline RQ & & & $* * *$ & $* * *$ & $*$ & NS \\
\hline
\end{tabular}

${ }_{\mathrm{z}}$ Mean values are based on 10 samples from each treatment across three experimental repetitions $(\mathrm{n}=30)$.

$\mathrm{y}_{\mathrm{NS}}, * * *, * * *$ Nonsignificant or significant at $P \leq 0.05,0.01$, or 0.001 , respectively.

${ }^{\mathrm{x}}$ Means sharing a letter within a $\mathrm{CO}_{2}$ concentration are not statistically different by Tukey's honestly significant difference test at $P \leq 0.05$. Means with no lettering were found to have no significant interaction between RI and RQ. 
The interaction between radiation intensity and quality was significant for LAI on days 14 and 21 at the $\mathrm{CO}_{2}$ concentration of $450 \mu \mathrm{mol} \cdot \mathrm{mol}^{-1}$ (Fig. 2). On day 14, LAI was lowest under $\mathrm{R}_{50}: \mathrm{B}_{50}$ at the radiation intensity of $150 \mu \mathrm{mol} \cdot \mathrm{m}^{-2} \cdot \mathrm{s}^{-1}$ compared with all other radiation treatments; however, by day $21 \mathrm{LAI}$ for seedlings under $\mathrm{R}_{50}: \mathrm{B}_{50}$ was lower than $\mathrm{R}_{90}: \mathrm{B}_{10}$ at both radiation intensities. Under the $\mathrm{CO}_{2}$ concentration of 900 $\mu \mathrm{mol} \cdot \mathrm{mol}^{-1}$ on day 21 , LAI was lower under $\mathrm{R}_{50}: \mathrm{B}_{50}$ at both radiation intensities compared with $\mathrm{R}_{90}: \mathrm{B}_{10}$ at the radiation intensity of $300 \mu \mathrm{mol} \cdot \mathrm{m}^{-2} \cdot \mathrm{s}^{-1}$ (Fig. 2). While no interaction was observed on day 28 at both $\mathrm{CO}_{2}$ concentrations, the main effect of radiation quality was significant for LAI with the lowest values observed under the radiation quality of $\mathrm{R}_{50}: \mathrm{B}_{50} \mathrm{com}$ pared with $\mathrm{R}_{90}: \mathrm{B}_{10}$ (data not shown). A curvilinear response between radiation absorption and LAI has been reported in several studies (Kim et al., 2004; Maddonni et al., 2001; Sarlikioti et al., 2011a). A typical LAI for annual crops is between 2 and 4 (Jonckheere et al., 2004), with petunia canopies considered closed when LAI > 3 (Lieth et al., 1991). In conventional field crops, a LAI between 3 and 5 results in incident radiation interception of $\approx 90 \%$ or more (Gallo et al., 1993; Maddonni and Otegui, 1996; Rosenthal et al., 1985). In our study, LAI was generally higher under the radiation quality of $\mathrm{R}_{90}: \mathrm{B}_{10}$ compared with $\mathrm{R}_{50}: \mathrm{B}_{50}$. This indicates a signifi- cantly larger fraction of incident radiation was not intercepted/ absorbed by seedlings grown under the radiation quality of $\mathrm{R}_{50}: \mathrm{B}_{50}$ compared with $\mathrm{R}_{90}: \mathrm{B}_{10}$, likely leading to the lower biomass accumulation observed under higher percentages of blue radiation. Additionally, as mentioned previously, LA expansion has been shown to be restricted by increased percentages of blue radiation (Hernández and Kubota, 2016; Ohashi-Kaneko et al., 2007), further accentuating the lower LAI and resulting biomass accumulation under the radiation quality of $\mathrm{R}_{50}: \mathrm{B}_{50}$.

No statistically significant interactive effects between radiation intensity and quality were observed for internode length among treatments. However, a significant main effect of radiation quality was observed for all days at both $\mathrm{CO}_{2}$ concentrations, with higher internode length under $\mathrm{R}_{90}: \mathrm{B}_{10}$ compared with $\mathrm{R}_{50}: \mathrm{B}_{50}$ (Fig. 2). Additionally, the main effect of radiation intensity was significant on days 14 and 21 at both $\mathrm{CO}_{2}$ concentrations, with higher internode length under 150 compared with $300 \mu \mathrm{mol} \cdot \mathrm{m}^{-2} \cdot \mathrm{s}^{-1}$ (data not shown). Increased internode length is a primary shade-avoidance response in many species to intercept and absorb more radiation (Franklin, 2008). For example, a decrease in internode length resulted in a large reduction in the percentage of radiation absorbed by tomato 'Aranca' plants (Sarlikioti et al., 2011b). One likely

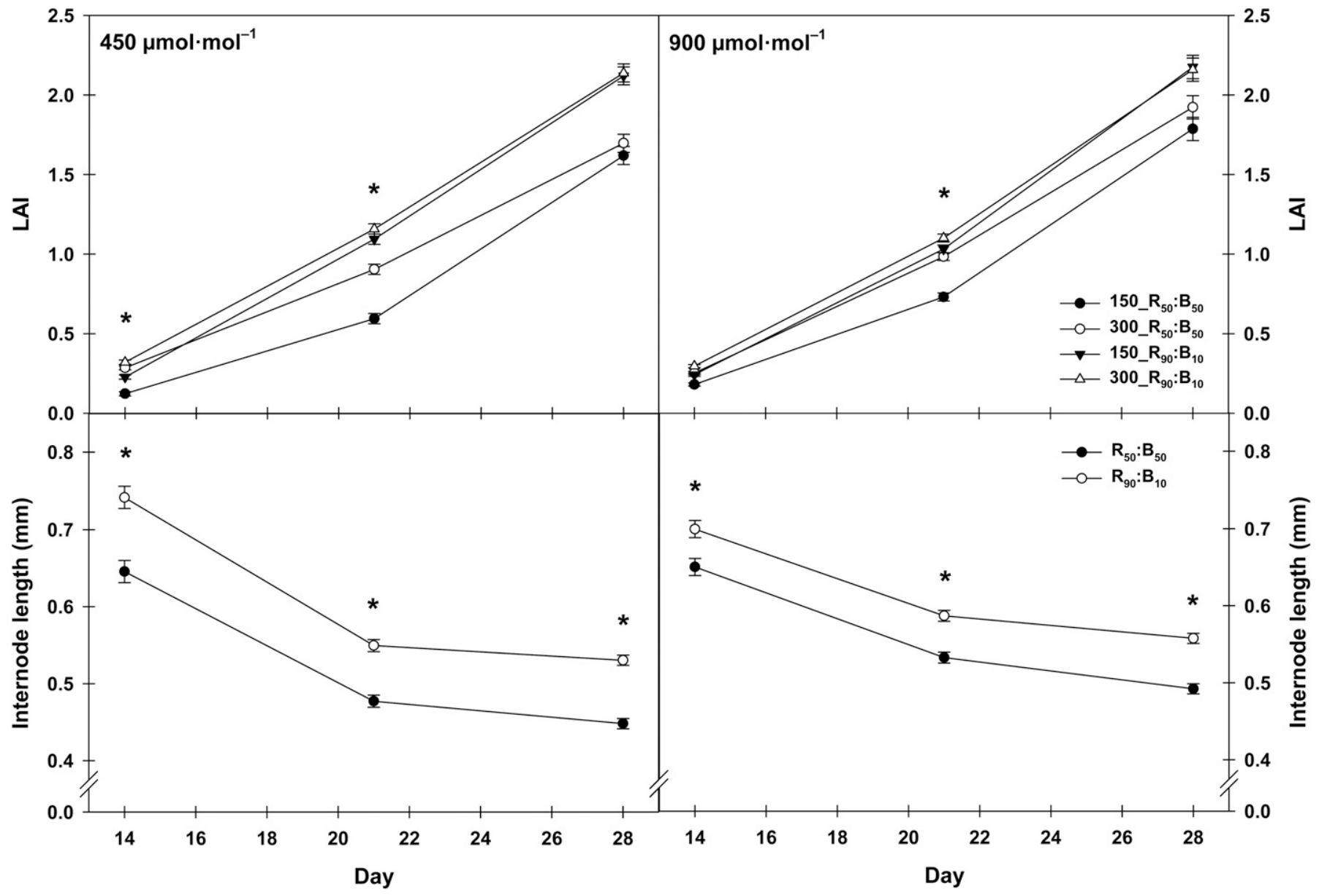

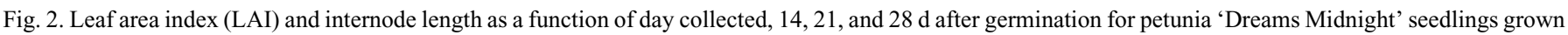
in walk-in growth chambers with $\mathrm{CO}_{2}$ concentration set points of 450 and $900 \mu \mathrm{mol} \cdot \mathrm{mol}^{-1}$ and sole-source light-emitting diode treatments with red:blue radiation quality ratios $(\%)$ of 90:10 $\left(\mathrm{R}_{90}: \mathrm{B}_{10}\right)$ and 50:50 $\left(\mathrm{R}_{50}: \mathrm{B}_{50}\right)$ at target radiation intensities of 150 and $300 \mu \mathrm{mol} \cdot \mathrm{m}^{-2} \cdot \mathrm{s}^{-1}$. Asterisks indicate a significant interaction $(P \leq 0.05)$ between radiation intensity and quality for LAI and a significant main effect $(P \leq 0.05)$ of radiation quality for internode length on the specified day. 
reason for lower radiation interception with shorter internodes is increased shading among the leaves in a canopy. A significantly lower internode length under the radiation quality of $\mathrm{R}_{50}: \mathrm{B}_{50}$ may indicate increased shading and decreased radiation interception/absorption compared with $\mathrm{R}_{90}: \mathrm{B}_{10}$.

Рнотosynthetic Responses. Whole-plant net photosynthetic rate increased asymptotically in all treatments with increasing $P P F D$, and the differences among treatments became larger beyond a $P P F D$ of $600 \mu \mathrm{mol} \cdot \mathrm{m}^{-2} \cdot \mathrm{s}^{-1}$ (Fig. 1). A-PPFD response curves (Fig. 1) indicated, while there was no interaction between radiation intensity and quality, the main effect of radiation quality was significant for $A_{g, \max }, A_{n, \max }$, $\mathrm{A}_{\text {op }}$, LCP, LSP, and $\alpha$ at both $\mathrm{CO}_{2}$ concentrations (Table 3 ). Specifically, higher values were observed for $A_{g, \max }, A_{n, \max }$, LCP, and LSP and lower values for $A_{\text {op }}$ and $\alpha$ under the radiation quality of $\mathrm{R}_{50}: \mathrm{B}_{50}$ compared with $\mathrm{R}_{90}: \mathrm{B}_{10}$ (Table 3 ). $A$ higher LCP under the radiation quality of $R_{50}: B_{50}$ suggests more radiation may have been necessary to offset losses from $R_{d}$ under increased percentages of blue radiation. The main effect of radiation intensity was also significant for LCP at both $\mathrm{CO}_{2}$ concentrations, with higher values under the radiation intensity of 300 compared with $150 \mu \mathrm{mol} \cdot \mathrm{m}^{-2} \cdot \mathrm{s}^{-1}$ (Table 3 ). This response is mainly due to higher rates of photosynthesis observed under high radiation intensities, ultimately resulting in higher (more negative) $R_{d}$ and a subsequent increase in the LCP to offset these losses for plants acclimated to high-light conditions (Boardman, 1977; Lichtenthaler et al., 1981).

Blue radiation has generally been labeled as less efficient at driving photosynthesis than red wavelengths, due in part to a low quantum efficiency (Cope et al., 2014). Part of the reason for this low quantum efficiency is due to the absorption of blue wavelengths by pigments other than chlorophylls (Barnes et al., 1993; Hogewoning et al., 2012). As a result, blue radiation generally has a lower $\alpha$ compared with red radiation (Evans,
1989; Hogewoning et al., 2012; McCree, 1972). Results from the present study support these findings, as $\alpha$ and $A_{o p}$ were significantly lower under the radiation quality of $\mathrm{R}_{50}: \mathrm{B}_{50}$ compared with $\mathrm{R}_{90}: \mathrm{B}_{10}$ at both $\mathrm{CO}_{2}$ concentrations (Table 3 ). In a previous work that used whole-plant photosynthesis measurements on wax begonia (Begonia semperflorens-cultorum) 'Cocktail Vodka', Nemali and van Iersel (2004) found increased LCP was associated with decreased $\alpha$, which further supports our findings. Additionally, the main effect of radiation intensity was significant for $\alpha$ at the $\mathrm{CO}_{2}$ concentration of 900 $\mu \mathrm{mol} \cdot \mathrm{mol}^{-1}$, with higher values observed under the radiation intensity of 150 compared with $300 \mu \mathrm{mol} \cdot \mathrm{m}^{-2} \cdot \mathrm{s}^{-1}$ (Table 3). A higher $\alpha$ for plants grown under a lower radiation intensity is expected, as plants are more efficient at using absorbed radiation in photosynthesis when radiation levels are limiting (Nemali and van Iersel, 2004).

Regardless of low $\alpha$, increasing blue radiation has been found to increase A in multiple species (Hogewoning et al., 2010; Huché-Thélier et al., 2016; Matsuda et al., 2007; Yorio et al., 2001), especially at higher radiation intensities. For example, Hogewoning et al. (2010) grew cucumber 'Hoffmann's Giganta' with red:blue radiation ratios of 100:0, 93:7, 88:12, $85: 15,70: 30,50: 50$, and 0:100 and found that as the percentage of blue radiation increased, $\mathrm{A}_{\mathrm{g}, \max }$, chlorophyll content, and $\mathrm{N}$ per unit LA increased. The authors concluded that $A_{g, \max }$ in cucumber responds quantitatively to increased blue radiation, stimulating a "sun-type" response in leaves even under the relatively low radiation intensity used for the study. This "suntype" response was outlined by Poorter et al. (2009), who stated that increased irradiance generally leads to a higher photosynthetic capacity and LMA.

In the present study, while LMA increased under the radiation intensity of $300 \mathrm{compared}$ with $150 \mu \mathrm{mol} \cdot \mathrm{m}^{-2} \cdot \mathrm{s}^{-1}$, differences in $A_{g, \max }$ and $A_{n, \max }$ were not observed. Comparable

Table 3. Parameters estimated from whole-plant photosynthesis (A) responses to to photosynthetic photon flux density ( $P P F D$ ) [A- $P P F D$ analysis (see Fig. 1 and Materials and Methods for more details)] including maximum gross photosynthetic rate $\left(\mathrm{A}_{\mathrm{g}, \mathrm{max}}\right)$, maximum net photosynthetic rate $\left(\mathrm{A}_{\mathrm{n}, \max }\right)$, photosynthetic rate at operating radiation intensity $\left(\mathrm{A}_{\mathrm{op}}\right)$, light compensation point (LCP), light saturation point (LSP), and quantum yield $(\alpha)$ for petunia 'Dreams Midnight' seedlings grown in walk-in growth chambers with $\mathrm{CO}_{2}$ concentration set points of 450 and $900 \mu \mathrm{mol} \cdot \mathrm{mol}^{-1}$ and sole-source light-emitting diode treatments with red:blue radiation quality (RQ) ratios (\%) of $90: 10$ and $50: 50$ at target radiation intensities (RIs) of 150 and $300 \mu \mathrm{mol} \cdot \mathrm{m}^{-2} \cdot \mathrm{s}^{-1}$.

\begin{tabular}{|c|c|c|c|c|c|c|c|c|}
\hline $\begin{array}{c}\mathrm{CO}_{2} \\
\left(\mu \mathrm{mol} \cdot \mathrm{mol}^{-1}\right)\end{array}$ & $\begin{array}{c}\text { Intensity } \\
\left(\mu \mathrm{mol} \cdot \mathrm{m}^{-2} \cdot \mathrm{s}^{-1}\right)\end{array}$ & $\begin{array}{c}\text { Quality } \\
\text { [red:blue (\%)] }\end{array}$ & \multicolumn{5}{|c|}{$\left(\mu \mathrm{mol} \cdot \mathrm{m}^{-2} \cdot \mathrm{s}^{-1}\right)$} & $\alpha\left(\mathrm{mol} \cdot \mathrm{mol}^{-1}\right)$ \\
\hline \multirow{2}{*}{450} & & $90: 10$ & 18.1 & 16.4 & 6.3 & 24.8 & 766 & 0.071 \\
\hline & & $90: 10$ & 17.9 & 15.8 & 10.1 & 32.9 & 792 & 0.068 \\
\hline RI & & & $\mathrm{NS}^{\mathrm{y}}$ & NS & $* * *$ & $*$ & NS & NS \\
\hline RQ & & & $* * *$ & $* * *$ & $* * *$ & $* * *$ & $* * *$ & $* * *$ \\
\hline \multirow[t]{4}{*}{900} & 150 & $50: 50$ & 26.9 & 24.8 & 6.0 & 33.9 & $1233 b^{x}$ & 0.065 \\
\hline & & $90: 10$ & 21.6 & 19.6 & 7.5 & 24.6 & $777 \mathrm{c}$ & 0.083 \\
\hline & 300 & $50: 50$ & 29.9 & 27.3 & 10.8 & 45.4 & $1506 \mathrm{a}$ & 0.060 \\
\hline & & $90: 10$ & 22.2 & 19.5 & 11.7 & 37.6 & $868 \mathrm{c}$ & 0.077 \\
\hline RI & & & NS & NS & $* * *$ & $* * *$ & $* * *$ & $* *$ \\
\hline RQ & & & $* * *$ & $* * *$ & $* * *$ & $* * *$ & $* * *$ & $* * *$ \\
\hline
\end{tabular}

${ }_{\mathrm{z}}$ Mean values are based on four samples from each treatment across three experimental repetitions $(\mathrm{n}=12)$.

$\mathrm{y}_{\mathrm{NS}}, * * *, * * *$ Nonsignificant or significant at $P \leq 0.05,0.01$, or 0.001 , respectively.

${ }^{\mathrm{x}}$ Means sharing a letter within a $\mathrm{CO}_{2}$ concentration are not statistically different by Tukey's honestly significant difference test at $P \leq 0.05$. Means with no lettering were found to have no significant interaction between RI and RQ. 
results were observed in begonia 'Cocktail Vodka', whereby $A_{g, \text { max }}$ and $A_{n, \text { max }}$ were similar for plants grown under a DLI of 14.4 and $19.4 \mathrm{~mol} \cdot \mathrm{m}^{-2} \cdot \mathrm{d}^{-1}$ (Nemali and van Iersel, 2004). Additionally, both $\mathrm{A}_{\mathrm{g} \text {,max }}$ and $\mathrm{A}_{\mathrm{n} \text {,max }}$ (on an LA basis) were highest under the radiation quality of $\mathrm{R}_{50}: \mathrm{B}_{50}$ at both $\mathrm{CO}_{2}$ concentrations. However, significant differences in LMA were not observed between radiation qualities. Murchie and Horton (1998) proposed that two levels of acclimation, chloroplast and leaf, exist regarding changes in $\mathrm{A}$. Therefore, like observations made by Matsuda et al. (2007), the increased $A_{n, \max }$ observed under the higher percentage of blue radiation was likely not a morphological "sun-type" irradiance response, as LMA was unaffected. Rather, we hypothesize that in petunia, increased $\mathrm{A}_{\mathrm{n}, \max }$ was due to acclimation at the chloroplast level.

The main effect of radiation quality for LUE was significant, except at the PPFD of $500 \mu \mathrm{mol} \cdot \mathrm{m}^{-2} \cdot \mathrm{s}^{-1}$, at both $\mathrm{CO}_{2}$ concentrations (Fig. 3). When PPFD levels were lower $(<500$ $\mu \mathrm{mol} \cdot \mathrm{m}^{-2} \cdot \mathrm{s}^{-1}$ ), LUE was higher under $\mathrm{R}_{90}: \mathrm{B}_{10}$ compared with $\mathrm{R}_{50}: \mathrm{B}_{50}$ regardless of radiation intensity and $\mathrm{CO}_{2}$ concentration; whereas at higher $P P F D$ levels $\left(>500 \mu \mathrm{mol} \cdot \mathrm{m}^{-2} \cdot \mathrm{s}^{-1}\right)$, LUE was higher under $\mathrm{R}_{50}: \mathrm{B}_{50}$ compared with $\mathrm{R}_{90}: \mathrm{B}_{10}$ (Fig. 3). Absorption of blue radiation by other pigments including carotenoids and anthocyanins is well known (Barnes et al., 1993; Hogewoning et al., 2012). Petunia plants grown under high radiation intensities have shown increased levels of carotenoid biosynthesis (Albert et al., 2009). Further, absorption of blue radiation by carotenoids has been previously documented (Barnes et al., 1993; Hogewoning et al., 2012). One probable reason for the observed lower and higher LUE under $\mathrm{R}_{50}: \mathrm{B}_{50}$ compared with $\mathrm{R}_{90}: \mathrm{B}_{10}$ when $P P F D$ was below and above $500 \mu \mathrm{mol} \cdot \mathrm{m}^{-2} \cdot \mathrm{s}^{-1}$, respectively, was likely due to increased biosynthesis of carotenoids and anthocyanins under $\mathrm{R}_{50}: \mathrm{B}_{50}$. Continuous exposure to increased blue radiation likely increased carotenoid and anthocyanin biosynthesis under the radiation quality of $\mathrm{R}_{50}: \mathrm{B}_{50}$ compared with $\mathrm{R}_{90}: \mathrm{B}_{10}$. When $P P F D$ was lower, absorption of blue radiation by these pigments likely lowered the total amount of radiation available for photochemistry, thereby lowering LUE for seedlings under the radiation quality of $\mathrm{R}_{50}: \mathrm{B}_{50}$ compared with $\mathrm{R}_{90}: \mathrm{B}_{10}$. As mentioned previously, this is also the likely reason for lower $A_{o p}$ and $\alpha$ under the radiation quality of $\mathrm{R}_{50}: \mathrm{B}_{50}$ compared with $\mathrm{R}_{90}: \mathrm{B}_{10}$ (Table 3). Short-term exposure to high radiation intensities can result in increased nonphotochemical quenching of "absorbed" radiation (Müller et al., 2001). Absorbed radiation must be used in photosynthesis or converted to thermal energy through the process of nonphotochemical quenching to avoid photoinhibition in plants (Brestic et al., 2014; Horton et al., 1996; Niyogi, 1999). The decline in LUE was greater under the radiation quality of $\mathrm{R}_{90}: \mathrm{B}_{10}$ above the $P P F D$ of $500 \mu \mathrm{mol} \cdot \mathrm{m}^{-2} \cdot \mathrm{s}^{-1}$, which was likely due to increased nonphotochemical quenching of "absorbed" radiation. Whereas it is possible that increased carotenoid and anthocyanin biosynthesis under $\mathrm{R}_{50}: \mathrm{B}_{50}$ absorbed excess radiation and resulted in lower nonphotochemical quenching and a more gradual decline in LUE with increasing PPFD.

The interaction between radiation intensity and quality was significant for $\mathrm{LSP}$ at the $\mathrm{CO}_{2}$ concentration of $900 \mu \mathrm{mol} \cdot \mathrm{mol}^{-1}$, with the highest LSP observed under $\mathrm{R}_{50}: \mathrm{B}_{50}$ at the radiation intensity of $300 \mu \mathrm{mol} \cdot \mathrm{m}^{-2} \cdot \mathrm{s}^{-1}$ (Table 3 ). The main effect of radiation quality was significant for LSP at the $\mathrm{CO}_{2}$ concentration of $450 \mu \mathrm{mol} \cdot \mathrm{mol}^{-1}$, with a higher LSP under the radiation quality of $\mathrm{R}_{50}: \mathrm{B}_{50}\left(1295 \mu \mathrm{mol} \cdot \mathrm{m}^{-2} \cdot \mathrm{s}^{-1}\right)$ compared with $\mathrm{R}_{90}: \mathrm{B}_{10}\left(779 \mu \mathrm{mol} \cdot \mathrm{m}^{-2} \cdot \mathrm{s}^{-1}\right)$. Albert et al. (2009) indicated anthocyanins are involved in screening the photosynthetic apparatus from high radiation intensities in petunia, with increased anthocyanins resulting in a higher LSP. An increase in LSP under higher percentages of blue radiation suggests carotenoid and anthocyanin biosynthesis likely increased under $\mathrm{R}_{50}: \mathrm{B}_{50}$ compared with $\mathrm{R}_{90}: \mathrm{B}_{10}$. Additionally, both $\mathrm{A}_{\mathrm{g}, \max }$ and $\mathrm{A}_{\mathrm{n}, \max }$ were highest under the radiation quality of $\mathrm{R}_{50}: \mathrm{B}_{50}$ at both $\mathrm{CO}_{2}$ concentrations (Table 3 ). At the $\mathrm{CO}_{2}$ concentration of $450 \mu \mathrm{mol} \cdot \mathrm{mol}^{-1}, \mathrm{~A}_{\mathrm{n}, \max }$ was $\approx 18 \%$ lower under the radiation quality of $\mathrm{R}_{90}: \mathrm{B}_{10}$ compared with $\mathrm{R}_{50}: \mathrm{B}_{50}$ (Table 3 ). Increases in $A_{g, \text { max }}$ and $A_{n, \text { max }}$ may be associated with higher LUE under the radiation quality of $\mathrm{R}_{50}: \mathrm{B}_{50}$ compared with $\mathrm{R}_{90}: \mathrm{B}_{10}$ at high radiation intensities (Fig. 3).

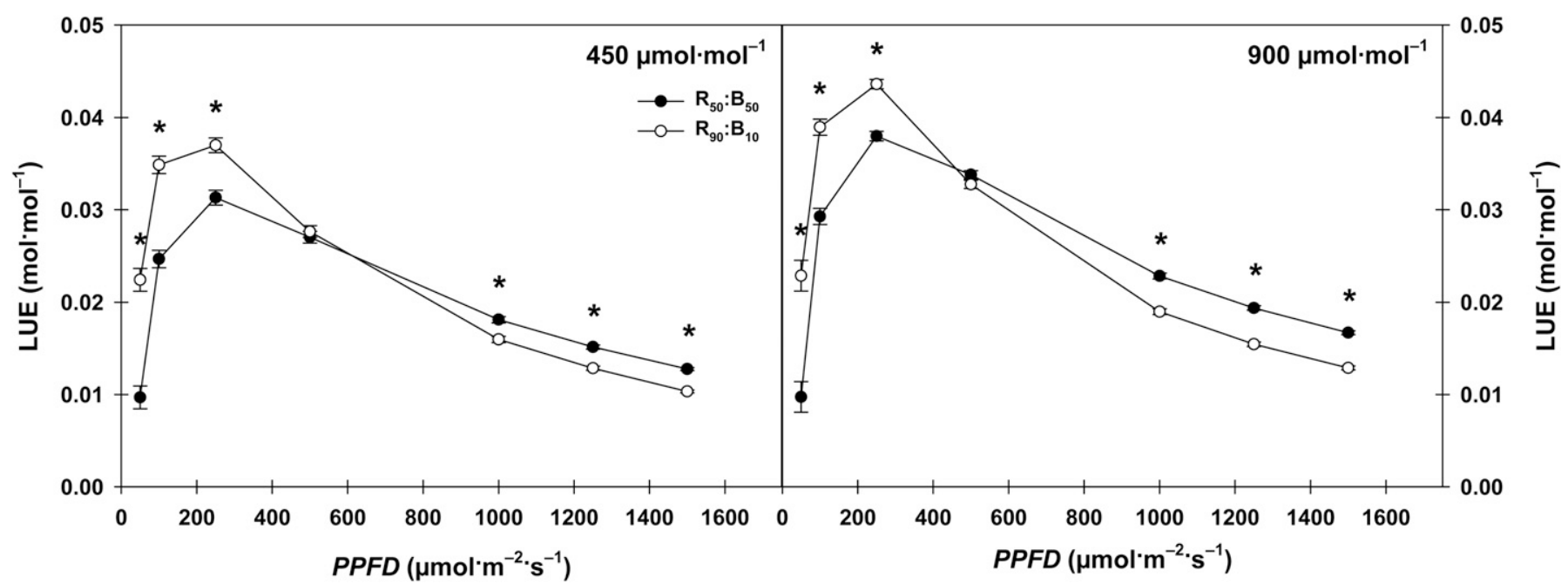

Fig. 3. Relationship between light use efficiency (LUE) and photosynthetic photon flux density (PPFD) for petunia 'Dreams Midnight' seedlings grown in walk-in growth chambers with $\mathrm{CO}_{2}$ concentration set points of 450 and $900 \mu \mathrm{mol} \cdot \mathrm{mol}^{-1}$ and sole-source light-emitting diode treatments with red:blue radiation quality ratios $(\%)$ of 90:10 $\left(\mathrm{R}_{90}: \mathrm{B}_{10}\right)$ and 50:50 $\left(\mathrm{R}_{50}: \mathrm{B}_{50}\right)$ at target radiation intensities of 150 and $300 \mu \mathrm{mol} \cdot \mathrm{m}^{-2} \cdot \mathrm{s}^{-1}$. The measurements were calculated from photosynthetic responses to increasing radiation taken $22 \mathrm{~d}$ after germination using a portable photosynthesis meter (LI-6400XT; LI-COR, Lincoln, NE). Asterisks indicate a significant main effect $(P \leq 0.05)$ of radiation quality at the specified $P P F D$. 
Previously, blue radiation was shown to increase stomatal aperture (Kinoshita et al., 2001; van Ieperen, 2012; Zeiger et al., 2002), thereby increasing the potential for $\mathrm{CO}_{2}$ uptake, which increases leaf photosynthesis (Kinoshita et al., 2001) or carboxylation rate. This finding may suggest that increased $\mathrm{CO}_{2}$ transfer into the leaf through increased stomatal opening is the primary mechanism for a blue-radiation-driven rise in leaf photosynthesis. Repeated measures analysis indicated a significant interaction between radiation intensity and quality on leaf photosynthesis of plants measured at ambient (400 $\mu \mathrm{mol} \cdot \mathrm{mol}^{-1}$ ) and subsequently at supra-optimal $\mathrm{CO}_{2}$ concentrations $\left(1000 \mu \mathrm{mol} \cdot \mathrm{mol}^{-1}\right)$. Leaf photosynthesis was higher at ambient and supra-optimal $\mathrm{CO}_{2}$ concentrations under $\mathrm{R}_{50}: \mathrm{B}_{50}$ compared with $\mathrm{R}_{90}: \mathrm{B}_{10}$ at the radiation intensity of 300 $\mu \mathrm{mol} \cdot \mathrm{m}^{-2} \cdot \mathrm{s}^{-1}$ but not at $150 \mu \mathrm{mol} \cdot \mathrm{m}^{-2} \cdot \mathrm{s}^{-1}$ (Fig. 4). However, the interaction between radiation quality and $\mathrm{CO}_{2}$ concentration on leaf photosynthesis was not significant (Fig. 4). This finding indicates that the magnitude of increase observed under $\mathrm{R}_{50}: \mathrm{B}_{50}$ compared with $\mathrm{R}_{90}: \mathrm{B}_{10}$ was not different between ambient and supra-optimal $\mathrm{CO}_{2}$ concentrations. At the supra-optimal $\mathrm{CO}_{2}$ concentration, leaf internal $\mathrm{CO}_{2}$ concentration was increased to a level higher than ambient. Under these conditions, leaf photosynthesis continued to be higher under $\mathrm{R}_{50}: \mathrm{B}_{50}$ compared with $\mathrm{R}_{90}: \mathrm{B}_{10}$. This indicates that the increase in leaf photosynthesis and LUE under $\mathrm{R}_{50}: \mathrm{B}_{50}$ compared with $\mathrm{R}_{90}: \mathrm{B}_{10}$ at high radiation intensities was likely not associated with increased carboxylation rate due to lower stomatal limitation for $\mathrm{CO}_{2}$ transfer. One possible reason is lower photoinhibition and increased photochemical quenching under $\mathrm{R}_{50}: \mathrm{B}_{50}$ compared with $\mathrm{R}_{90}: \mathrm{B}_{10}$ at high radiation intensities from increased biosynthesis of carotenoids and anthocyanins.

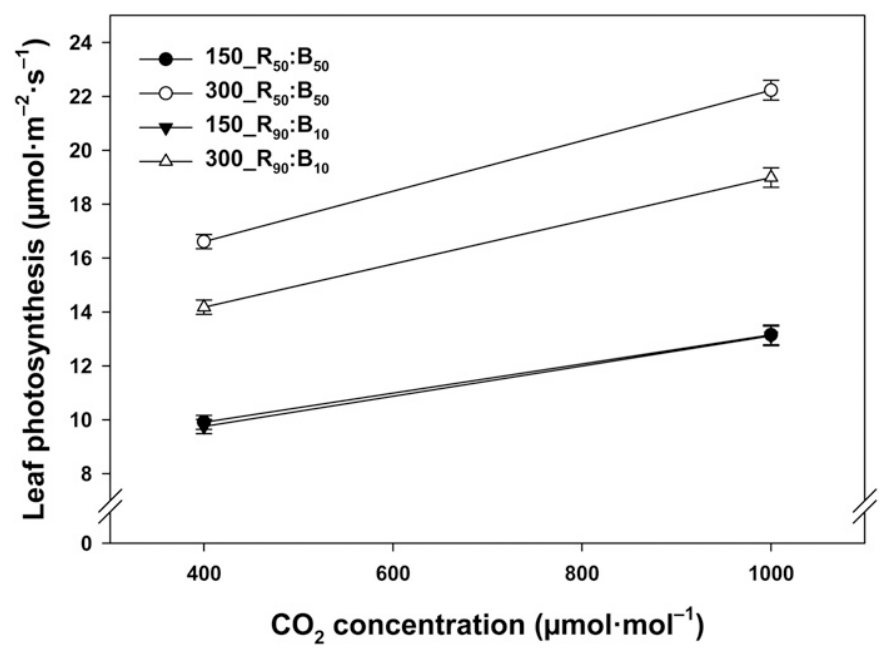

Fig. 4. Interactive effect of radiation intensity and quality on leaf photosynthesis for petunia 'Dreams Midnight' seedlings measured at ambient (400 $\left.\mu \mathrm{mol} \cdot \mathrm{mol}^{-1}\right)$ and subsequently at supra-optimal $\mathrm{CO}_{2}$ concentrations (1000 $\mu \mathrm{mol} \cdot \mathrm{mol}^{-1}$ ). Plants were grown in a walk-in growth chamber with a $\mathrm{CO}_{2}$ concentration set point of $450 \mu \mathrm{mol} \cdot \mathrm{mol}^{-1}$ and sole-source light-emitting diode treatments with red:blue radiation quality ratios $(\%)$ of $90: 10\left(\mathrm{R}_{90}: \mathrm{B}_{10}\right)$ and 50:50 $\left(\mathrm{R}_{50}: \mathrm{B}_{50}\right)$ at target radiation intensities of 150 and $300 \mu \mathrm{mol} \cdot \mathrm{m}^{-2} \cdot \mathrm{s}^{-1}$. Both ambient and supra-optimal measurements were made on the same plants $29 \mathrm{~d}$ after germination using a portable photosynthesis meter (LI-6400XT; LICOR, Lincoln, NE) to study effects of stomatal and nonstomatal limitations to photosynthesis. A significant interaction between radiation intensity and quality was observed at both $\mathrm{CO}_{2}$ concentrations by Tukey's honestly significant difference test at $P \leq 0.05$.
RELATION BETWEEN GROWTH AND PHOTOSYNTHETIC RESPONSES UNDER INCREASED BLUE RADIATION. Our results indicate petunia seedlings, when exposed to high-energy blue radiation, respond by increasing photosynthesis at the leaf scale (especially at high radiation intensities) and lowering their leaf area and light interception at the whole-plant scale. Contrary to the generally accepted relationship between increased LMA and leaf photosynthesis under a high proportion of blue light, there were no differences in LMA in petunia despite differences in A between both radiation quality treatments. It is possible that exposure to high proportions of blue radiation can result in increased biosynthesis of carotenoids and anthocyanins at a cellular scale, based on lower $\mathrm{A}_{\mathrm{op}}$ and $\alpha$ and higher LCP, LSP, and LUE (at high radiation intensities) in our study. These pigments can increase LUE under high radiation intensities due to reduced photoinhibition, resulting in increased photochemical quenching. Based on the observed responses for petunia seedlings, high-energy blue radiation reduces leaf expansion, which further reduces the interception of this radiation; however, plant biomass accumulation also decreases due to reduced radiation interception, resulting in small (but not compact) seedlings.

\section{Conclusion}

While previous studies have evaluated the feasibility of seedling production in indoor environments using LED SSL, few have reported physiological responses to multiple inputs under these conditions. With increased understanding of these responses, production in controlled environments can be more effectively optimized. Our results indicate seedling growth under higher percentages of blue radiation is affected by acclimation responses at various scales. The present study provides a foundation for future research to elucidate how radiation intensity and quality can be used alongside elevated $\mathrm{CO}_{2}$ to optimize seedling growth and decrease production time for the efficient use of energy and indoor space.

\section{Literature Cited}

Albert, N.W., D.H. Lewis, H. Zhang, L.J. Irving, P.E. Jameson, and K.M. Davies. 2009. Light induced vegetative anthocyanin pigmentation in Petunia. J. Expt. Bot. 60:2191-2202.

Arp, W.J. 1991. Effects of source-sink relations on photosynthetic acclimation to elevated $\mathrm{CO}_{2}$. Plant Cell Environ. 14:869-875.

Banerjee, C. and L. Adenaeuer. 2014. Up, up and away! The economics of vertical farming. J. Agr. Studies 2(1):40-60.

Barnes, C., T. Tibbitts, J. Sager, G. Deitzer, D. Bubenheim, G. Koerner, and B. Bugbee. 1993. Accuracy of quantum sensors measuring yield photon flux and photosynthetic photon flux. HortScience 28:1197-1200.

Boardman, N.K. 1977. Comparative photosynthesis of sun and shade plants. Annu. Rev. Plant Physiol. 28:355-377.

Brestic, M., M. Zivcak, K. Olsovska, H.-B. Shao, H.M. Kalaji, and S.I. Allakhverdiev. 2014. Reduced glutamine synthetase activity plays a role in control of photosynthetic responses to high light in barley leaves. Plant Physiol. Biol. 81:74-83.

Cope, K.R., M.C. Snowden, and B. Bugbee. 2014. Photobiological interactions of blue light and photosynthetic photon flux: Effects of monochromatic and broad-spectrum light sources. Photochem. Photobiol. 90:574-584.

Cosgrove, D.J. 1981. Rapid suppression of growth by blue light. Plant Physiol. 67:584-590.

Evans, J.R. 1989. Photosynthesis and nitrogen relationships in leaves of $\mathrm{C}_{3}$ plants. Oecologia 78:9-19. 
Faust, J.E., V. Holcombe, N.C. Rajapakse, and D.R. Layne. 2005. The effect of daily light integral on bedding plant growth and flowering. HortScience 40:645-649.

Franklin, K.A. 2008. Shade avoidance. New Phytol. 179:930-944.

Gallo, K.P., C.S.T. Daughtry, and C.L. Wiegand. 1993. Errors in measuring absorbed radiation and computing crop radiation use efficiency. Agron. J. 85:1222-1228.

Graper, D.F. and W. Healy. 1991. High pressure sodium irradiation and infrared radiation accelerate Petunia seedling growth. J. Amer. Soc. Hort. Sci. 116:435-438.

Graper, D.F. and W. Healy. 1992. Modification of petunia seedling carbohydrate partitioning by irradiance. J. Amer. Soc. Hort. Sci. 117:477-480.

Hernández, R. and C. Kubota. 2016. Physiological responses of cucumber seedlings under different blue and red photon flux ratios using LEDs. Environ. Expt. Bot. 121:66-74.

Hogewoning, S.W., E. Wientjes, P. Douwstra, G. Trouwborst, W. van Ieperen, R. Croce, and J. Harbinson. 2012. Photosynthetic quantum yield dynamics: From photosystems to leaves. Plant Cell 24:19211935.

Hogewoning, S.W., G. Trouwborst, H. Maljaars, H. Poorter, W. van Ieperen, and J. Harbinson. 2010. Blue light dose-responses of leaf photosynthesis, morphology, and chemical composition of Cucumis sativus grown under different combinations of red and blue light. J. Expt. Bot. 61:3107-3117.

Horton, P., A.V. Ruban, and R.G. Walters. 1996. Regulation of light harvesting in green plants. Annu. Rev. Plant Physiol. Plant Mol. Biol. 47:655-684.

Huché-Thélier, L., L. Crespel, J.L. Gourrierec, P. Morel, S. Sakr, and N. Leduc. 2016. Light signaling and plant responses to blue and UV radiations-Perspectives for applications in horticulture. Environ. Expt. Bot. 121:22-38.

Jonckheere, I., S. Fleck, K. Nackaerts, B. Muys, P. Coppin, M. Weiss, and F. Baret. 2004. Review of methods for in situ leaf area index determination. Part I, Theories, sensors and hemispherical photography. Agr. For. Meteorol. 121:19-35.

Kigel, J. and D.J. Cosgrove. 1991. Photoinhibition of stem elongation by blue and red light. Plant Physiol. 95:1049-1056.

Kim, H.-H., G.D. Goins, R.M. Wheeler, and J.C. Sager. 2004. Greenlight supplementation for enhanced lettuce growth under red- and blue-light-emitting diodes. HortScience 39:1617-1622.

Kinoshita, T., M. Doi, N. Suetsugu, T. Kagawa, M. Wada, and K. Shimazaki. 2001. Phot 1 and phot 2 mediate blue light regulation of stomatal opening. Nature 414:656-660.

Kopsell, D.A., C.E. Sams, T.C. Barickman, and R.C. Morrow. 2014. Sprouting broccoli accumulate higher concentrations of nutritionally important metabolites under narrow-band light-emitting diode lighting. J. Amer. Soc. Hort. Sci. 139:469-477.

Lichtenthaler, H.K., C. Buschmann, M. Döll, H.-J. Fietz, T. Bach, U. Kozel, D. Meier, and U. Rahmsdorf. 1981. Photosynthetic activity, chloroplast ultrastructure, and leaf characteristics of high-light and low-light plants and of sun and shade leaves. Photosynth. Res. 2:115141.

Lieth, J.H., R.H. Merritt, and H.C. Kohl, Jr. 1991. Crop productivity of petunia in relation to photosynthetically active radiation and air temperature. J. Amer. Soc. Hort. Sci. 116:623-626.

Maddonni, G.A. and M.E. Otegui. 1996. Leaf area, light interception, and crop development in maize. Field Crops Res. 48:81-87.

Maddonni, G.A., M.E. Otegui, and A.G. Cirilo. 2001. Plant population density, row spacing and hybrid effects on maize canopy architecture and light attenuation. Field Crops Res. 71:183-193.

Makino, A. and T. Mae. 1999. Photosynthesis and plant growth at elevated levels of $\mathrm{CO}_{2}$. Plant Cell Physiol. 40:999-1006.

Massa, G.D., H. Kim, R.M. Wheeler, and C.A. Mitchell. 2008. Plant productivity in response to LED lighting. HortScience 43:1951-1956.

Matsuda, R., K. Ohashi-Kaneko, K. Fujiwara, and K. Kurata. 2007. Analysis of the relationship between blue-light photon flux density and the photosynthetic properties of spinach (Spinacia oleracea L.) leaves with regard to the acclimation of photosynthesis to growth irradiance. Soil Sci. Plant Nutr. 53:459-465.

McCree, K.J. 1972. The action spectrum, absorptance and quantum yield of photosynthesis in crop plants. Agric. Meteorol. 9:191216.

Mitchell, C.A., A. Both, C.M. Bourget, J.F. Burr, C. Kubota, R.G. Lopez, R.C. Morrow, and E.S. Runkle. 2012. LEDs: The future of greenhouse lighting! Chronica Hort. 52(1):6-12.

Müller, P., X.-P. Li, and K.K. Niyogi. 2001. Non-photochemical quenching. A response to excess light energy. Plant Physiol. 125:1558-1566.

Murchie, E.H. and P. Horton. 1998. Contrasting patterns of photosynthetic acclimation to the light environment are dependent on the differential expression of the responses to altered irradiance and spectral quality. Plant Cell Environ. 21:139-148.

Nemali, K.S. and M.W. van Iersel. 2004. Light effects on wax begonia: Photosynthesis, growth respiration, maintenance respiration, and carbon use efficiency. J. Amer. Soc. Hort. Sci. 129:416-424.

Niyogi, K.K. 1999. Photoprotection revisited: Genetic and molecular approaches. Annu. Rev. Plant Physiol. Plant Mol. Biol. 50:333-359.

Oh, W., E.S. Runkle, and R.M. Warner. 2010. Timing and duration of supplemental lighting during the seedling stage influence quality and flowering in petunia and pansy. HortScience 45:1332-1337.

Ohashi-Kaneko, K., M. Takase, N. Kon, K. Fujiwara, and K. Kurata. 2007. Effect of light quality on growth and vegetable quality in leaf lettuce, spinach and komatsuna. Environ. Control Biol. 45:189-198.

Park, Y. and E.S. Runkle. 2017. Far-red radiation promotes growth of seedlings by increasing leaf expansion and whole-plant net assimilation. Environ. Expt. Bot. 136:41-49.

Poorter, H., U. Niinemets, L. Poorter, I.J. Wright, and R. Villar. 2009. Causes and consequences of variation in leaf mass per area (LMA): A meta-analysis. New Phytol. 182:565-588.

Pramuk, L.A. and E.S. Runkle. 2005. Photosynthetic daily light integral during the seedling stage influences subsequent growth and flowering of Celosia, Impatiens, Salvia, Tagetes, and Viola. HortScience 40:1336-1339.

Prior, S.A., G.B. Runion, S.C. Marble, H.H. Rogers, C.H. Gilliam, and H.A. Torbert. 2011. A review of elevated atmospheric $\mathrm{CO}_{2}$ effects on plant growth and water relations: Implications for horticulture. HortScience 46:158-162.

Randall, W.C. and R.G. Lopez. 2015. Comparison of bedding plant seedlings grown under sole-source light-emitting diodes (LEDs) and greenhouse supplemental lighting from LEDs and high-pressure sodium lamps. HortScience 50:705-713.

Rosenthal, W.D., G.F. Arkin, and T.A. Howell. 1985. Transmitted and absorbed photosynthetically active radiation in grain sorghum. Agron. J. 77:841-845.

Runkle, E.S. and R.D. Heins. 2001. Specific functions of red, far red, and blue light in flowering and stem extension of long-day plants. J. Amer. Soc. Hort. Sci. 126:275-282.

Sarlikioti, V., E. Meinen, and L.F.M. Marcelis. 2011a. Crop reflectance as a tool for the online monitoring of LAI and PAR interception in two different greenhouse crops. Biosyst. Eng. 108:114-120.

Sarlikioti, V., P.H.B. de Visser, G.H. Buck-Sorlin, and L.F.M. Marcelis. 2011b. How plant architecture affects light absorption and photosynthesis in tomato: Towards an ideotype for plant architecture using a functional-structural plant model. Ann. Bot. 108:1065-1073.

Shimizu, H., Y. Saito, H. Nakashima, J. Miyasaka, and K. Ohdoi. 2011. Light environment optimization for lettuce growth in plant factory. IFAC Proc. 44:605-609.

Tremblay, N. and A. Gosselin. 1998. Effect of carbon dioxide enrichment and light. HortTechnology 8:524-528.

van Ieperen, W. 2012. Plant morphological and developmental responses to light quality in a horticultural context. Acta Hort. 956:131-139. 
Wollaeger, H.M. and E.S. Runkle. 2014. Producing commercialquality ornamental seedlings under sole-source LED lighting. Acta Hort. 1037:269-276

Yorio, N.C., G.D. Goins, H.R. Kagie, R.M. Wheeler, and J.C. Sager. 2001. Improving spinach, radish, and lettuce growth under red light-emitting diodes (LEDs) with blue light supplementation. HortScience 36:380383.

Zeiger, E., L.D. Talbott, S. Frechilla, A. Srivastava, and J. Zhu. 2002. The guard cell chloroplast: A perspective for the twenty-first century. New Phytol. 153:415-424. 